\title{
Pengaruh Bauran Pemasaran Dan Analisis Optimalisasi Faktor Produksi Pada Industri Kecil Sari Kedelai NONY di Kabupaten Tulungagung
}

\section{The Influence of Marketing Mix And Optimization Analysis Of Production Factor In Small Industry Sari NONY in Tulungagung District}

\author{
Program Arryanto Putra
}

\author{
Program Studi Magister Agribisnis Program Pascasarjana
}

Universitas Islam Kadiri

Jl. Sersan Suharmaji No. 38 Kota Kediri Jawa Timur Telp./Fax. (0354) 683243

\begin{abstract}
Abstrak
NONY merupakan salah satu bentuk usaha kecil yang bergerak di bidang agribisnis pengolahan makanan hasil pertanian berupa sari kedelai. Namun seiring berjalanannya waktu, semakin banyak pula pelaku usaha yang bergerak dibidang yang sama. Hal ini tentunya akan mengancam eksistensi perusahaan NONY dalam memproduksi sari kedelai, berbagi macam strategi harus dilakukan agar perusahaan ini dapat bertahan. Oleh karena itu perlu dilakukan analisis optimalisasi faktor produksi untuk mengetahui faktor produksi apa saja yang perlu ditingkatkan maupun dikurangi. Selain itu hal yang penting adalah dari sisi pemasaram, perusahan NONY perlu melakukan analisis bauran pemasaran terhadap kepusan konsumen agar dapat menjaga loyalitas konsumen yang membuat perusahaan dapat bertahan.

Penelitian ini menggunakan metode penelitian regresi linier berganda untuk mencari analisis optimalisasi faktor produksi dan analisis bauran pemasaran terhadap kepusan konsumen sari kedelai NONY. Untuk analisis optimalisasi faktor produksi menggunakan analisisi faktor produksi Cobb Douglas. Menggunakan 100 sampel terscreening agar didapatkan hasil yang baik, yang dilanjutkan dengan mencari pengaruh bauran pemasaran terhadap konsumen

Hasil Penelitian menunjukkan bahwa faktor produksi gula sangat berpengaruh terhadap proses produksi sari kedelai NONY dan perlu dilakukan pengurangan penggunaan perasa dan pekerja untuk meningkatkan optimalisasi produksi.Faktor Produk dan Promosi dalam bauran pemasaran sangat mempengaruhi kepuasan dan loyalitas konsumen, dimana konsumen dari sari kedelai NONY ini masuk dalam kategori sedang.

Kata Kunci : Sari Kedelai,Optimalisasi Faktor Produksi, Bauran Pemasaran, Kepuasan dan Loylitas Konsumen
\end{abstract}

\section{Abstract}

NONY is one form of small business engaged in the agribusiness processing of agricultural products in the form of soy extract. But as time passes, more and more business actors engaged in the same field. This will undoubtedly threaten the existence of NONY company in producing soybean extract, sharing various strategies must be done so that this company can survive. Therefore it is necessary to analyze the optimization of production factors to determine what production factors need to be improved or reduced. Also important thing is from marketing side, NONY company need to do marketing mix analysis satisfyed consumer in order to maintain customer loyalty that make company can survive.

This study uses multiple linear regression method to find analysis of factor optimization and marketing mix analysis to NONY soybean consumers. For analysis of production factor optimization using Cobb Douglas factor input analysis. Using 100 screening samples in order to obtain good results, followed by looking for the influence of marketing mix to consumers

The result of this research shows that sugar production factor is very influential to NONY soybean production process and it is necessary to reduce the use of taste and worker 
to increase the optimization of production. Product and Promotion factor in marketing mix influences consumer's satisfaction and loyalty, where the consumer of NONY soybean extract comes in. in the medium category.

Keywords: Soybean, Production Factor Optimization, Marketing Mix, Consumer Satisfaction and Loyalty

\section{PENDAHULUAN}

Industri kecil di Indonesia merupakan bagian penting dalam sistem perekonomian nasional dalam mempercepat pertumbuhan ekonomi, peningkatan pendapatan masyarakat, peningkatan devisa serta memperkokoh struktur industri nasional. Salah satu industri kecil yang potensial adalah industri makanan dan minuman, semenjak tahun 2013 sampai 2016 terjadi penigkatan jumlah pelaku industri dibidang ini, hal ini menuntut para pengusaha agar selalu memahami apa yang menjadi keinginan konsumen serta mengetahui perubahan yang ada agar mampu bersaing. Perubahan selera konsumen, teknologi dan persaingan yang pesat menuntut agar perusahaan harus selalu melakukan pengembangan produk (Kemenperin,2016).

Salah satu cabang agroindustri adalah pengolahan bahan hasil pertanian, sifat hasil panen yang mudah rusak ini menjadi peluang bagi para pelaku usaha kreatif untuk meningkatkan nilai jual. Di Indonesia hampir seluruh komoditas hasil pertanian dapat diolah, salah satunya dalah kedelai. Kedelai merupakan salah satu komoditas pangan utama disamping padi dan jagung. Kebutuhan terhadap industri olahan yang berbahan baku kedelai seperti tahu, tempe, tauco, kecap, susu kedelai dan bahan baku pakan ternak terus meningkat dari tahun ke tahun.

Sari kedelai merupakan salah satu produk olahan yang berbahan baku kedelai. Sari kedelai akhir-akhir ini telah banyak dikenal sebagai susu alternatif pengganti susu sapi. Hal ini dikarenakan sari kedelai memiliki kandungan protein yang cukup tinggi dengan harga relatif lebih murah jika dibandingkan dengan sumber protein lainnya. Protein sari kedelai memiliki susunan asam amino yang hampir sama dengan susu sapi sehingga sari kedelai seringkali digunakan sebagai pengganti susu sapi bagi mereka yang alergi terhadap protein hewani. Selain itu sari kedelai juga mengandung lemak, karbohidrat, kalsium, posphor, zat besi, provitamin A, vitamin B kompleks, dan air, sari kedelai dapat dibuat dengan cara dan alat yang sederhana,tidak memerlukan keahlian khusus, namun memerlukan perlakuan khusus (Antuni, 2014).

Skala usaha dari industri sari kedelai belum terlalu besar jika dibandingkan dengan pengolahan susu sapi.. Namun jika dilihat dari penjualannya setiap tahun, sari kedelai memiliki prospek ke depan yang sangat bagus, karena terus mengalami peningkatan. Hal ini mengidentifikasikan bahwa industri kecil ini memiliki potensi yang besar untuk berkembang. Namun fakta dilapangan membuktikan bahwa pengelolaan industri ini masih perlu pengembangan lagi terutama pada bagian produksi dan pemasaran. Berdasarkan pernyataan diatas perlu dilakukan penelitian untuk mencari tahu pengaruh bauran pemasaran terhadap kepuasan konsumen dan loyalitas konsumen serta analisi faktor produksi yang optimal dari industri sari kedelai ini. Informasi ini nantinya dapat digunakan sebagai sarana pengembangan industri kecil menjadi lebih besar lagi.

\section{METODE PENELITIAN}

\section{Waktu dan Tempat Penelitian}

Penelitian ini dilaksanakan di Usaha Sari Kedelai NONY desa Sambitan, Kecamatan Pekel, Kabupaten Tulungagung, Provinsi Jawa timur dan dilaksanakan pada bulan September 2017 sampai dengan Oktober 2017 dengan asumsi tidak adanya perubahan implementasi proses produksi dan sistem bauran pemasarannya.

\section{Jenis-jenis dan Sumber Data}

Jenis dan sumber data yang digunakan dalam penelitian ini adalah data primer dan data sekunder. Data primer 
diperoleh dari pihak internal Industri Sari

Kedelai NONYyang diperoleh melalui metode depth interview, focus group discussion (FGD) dan pengolahan kuesioner oleh Konsumen sari kedelai produk NONY, data produksi sekali siklus, data pemakaian faktor produksi sekali siklus. Sedangkan data sekunder diperoleh dari laporan tahunan, studi literatur dari Dinas Perindustrian dan Perdagangan Kabupaten Tulungagung, literatur-literatur lainnya seperti buku, Thesis dan jurnal yang relevan dengan penelitian ini, dan juga internet.

\section{Metode Pengambilan Sampel}

Metode pengambilan sampel dalam optimalisasi faktor produksi dilakukan dengan metode sensus, yaitu dengan memperoleh informasi sebanyak mungkin dari objek penelitian. Sementara metode untuk evaluasi bauran pemasaran menggunakan convenience sampling yang didahului oleh pemilihan konsumen. Konsumen yang dipilih harus berusia diatas 17 tahun atau lebih serta telah mengkonsumsi sari kedelai lebih dari satu kali. Total sampel pada penelitian ini sebanyak 100 orang.

\section{Metode Analisis Data}

\section{Optimalisasi Produksi Douglas)}

(Cobb

Untuk mengetahui optimalisasi faktor - faktor produksi diukur dengan fungsi Cobb Douglas. Faktor-faktor yang menjadi penduga fungsi produk dalam penelitian ini adalah kedelai, gula, garam, air, perasa pewarna aroma makanan, tenaga kerja dan investasi. Untuk memudahkan dalam pendugaan persamaan ditulis dalam bentuk linear dan diolah dengan regresi berganda menggunakan SPSS. Persamaan liner dari fungsi Cobb douglas adalah sebagai berikut :

$\operatorname{Ln} Y=\operatorname{Ln} a+b 1 \operatorname{Lnx} 1+b 2 \operatorname{Ln} x 2+$ b3 $\operatorname{Lnx} 3+$ b4 $\operatorname{Ln} x 4+$ b5 $\operatorname{Ln} x 5+$ b6 $\operatorname{Ln} \times 6+b 7 \operatorname{Ln} \times 7+u$

Dimana :

$\mathrm{Y}=$ produksi sari kedelai ( Liter per satuan siklus produksi )

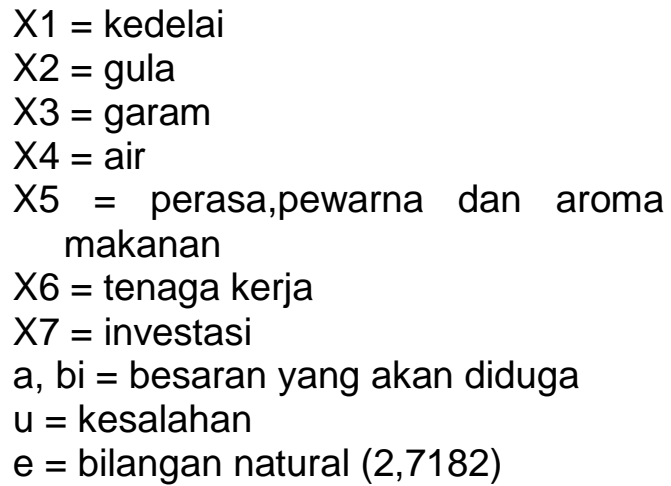

\section{Bauran Pemasaran}

Untuk menentukan bauran pemasaran yang tepat digunakan metode analisa regresi linear dengan menentukan indikator sebagai berikut:

\begin{tabular}{|c|c|c|}
\hline \multicolumn{3}{|l|}{$\begin{array}{l}\text { Variabel } \\
\text { Eksogen }\end{array}$} \\
\hline \multicolumn{3}{|l|}{ Eksogen } \\
\hline Product & $\begin{array}{l}\text { - Cita rasa sari } \\
\text { kedelai } \\
\text { - Takaran saji } \\
\text { - Tekstur sari } \\
\text { kedelai } \\
\text { - Tamnilan }\end{array}$ & $\begin{array}{l}X 11 \\
X 12 \\
X 13 \\
X 14 \\
\text { X15 } \\
\text { X16 }\end{array}$ \\
\hline Price & $\begin{array}{l}\text { kemasan } \\
\text { - Kebersihan sari } \\
\text { kedelai }\end{array}$ & $\times 21$ \\
\hline People & $\begin{array}{l}\text { - Varian rasa } \\
\text { - Kesesuaian }\end{array}$ & $\begin{array}{l}\text { X31 } \\
\text { X32 }\end{array}$ \\
\hline Process & $\begin{array}{l}\text { harga yang } \\
\text { ditawarkan }\end{array}$ & X41 \\
\hline Place & $\begin{array}{l}\text { dengan kualitas } \\
\text { produk }\end{array}$ & $\times 51$ \\
\hline $\begin{array}{l}\text { Physical } \\
\text { Evidance }\end{array}$ & $\begin{array}{ll}\text { - } & \text { Keramahan dan } \\
\text { etos } & \text { kerja } \\
\text { karyawan }\end{array}$ & $\begin{array}{l}X 61 \\
\times 62\end{array}$ \\
\hline & & X63 \\
\hline Promotion & $\begin{array}{l}\text { keterampilan } \\
\text { - Kebiasaan }\end{array}$ & $\begin{array}{l}X 71 \\
\text { X72 }\end{array}$ \\
\hline & $\begin{array}{l}\text { untuk menaati } \\
\text { SOP produksi } \\
\text { - } \text { Lokasi pabrik } \\
\text { dan showroom } \\
\text { - } \text { Tata ruang } \\
\text { pabrik } \\
\text { - Kebersihan alat } \\
\text { dan ruang } \\
\text { - Kapabilitas } \\
\text { ruang } \\
\text { penyimpanan }\end{array}$ & \\
\hline
\end{tabular}




\begin{tabular}{|c|c|c|}
\hline & $\begin{array}{l}\text { - } \text { Papan nama } \\
\text { pabrik } \\
\text { - Promosi melalui } \\
\text { media cetak } \\
\text { dan elektronik }\end{array}$ & \\
\hline \multicolumn{3}{|l|}{ Endogen } \\
\hline $\begin{array}{l}\text { Kepuasan } \\
\text { Loyalitas }\end{array}$ & $\begin{array}{l}\text { - Kepuasan } \\
\text { secara } \\
\text { menyeluruh } \\
\text { - Keinginan } \\
\text { untuk } \\
\text { mengkonsumsi } \\
\text { kembali } \\
\text { - Resisten } \\
\text { terhadap harga } \\
\text { - Rekomendasi } \\
\text { kepada orang } \\
\text { lain }\end{array}$ & $\begin{array}{l}\mathrm{Y} 1 \\
\mathrm{Y} 2 \\
\mathrm{Y3} \\
\mathrm{Y4}\end{array}$ \\
\hline
\end{tabular}

Ketepatan suatu model yang digunakan sebagai alat analisis diuji dengan uji statistik sebgai berikut :

1. Uji Statistik $\mathrm{t}$

Digunakan untuk mengetahui seberapa jauh masing - masing faktor produksi (xi) sebagai variabel bebas mempengaruhi produksi (y) . prosedur pengujian sebagai berikut

Ho : bi = 0 (tidak ada pengaruh)

$\mathrm{H} 1: \mathrm{bi} \neq \mathrm{O}$ ( ada pengaruh)

$t_{\text {hitung }}=(\mathrm{bi}-0) / \mathrm{sbi}$

jika $t_{\text {hitung }} \leq t_{\text {tabel }}$, maka Ho diterima, artinya $\mathrm{xi}$ tidak berpengaruh nyata terhadap y

jika $t_{\text {hitung }}>t_{\text {tabel }}$, maka Ho ditolak, artinya xi berpengaruh nyata terhadap y

2. Uji statistik $F$

Untuk mengetahui faktor produksi xi secar abersama -sama terhadap produksi (y). Hipotesis yang diuji adalah

Ho : bi = b2 = b3 = b4 =0

$\mathrm{H} 1: 1 \mathrm{~b} 1 \neq 0$ ata $\mathrm{b} 4 \neq 0$

$\left.F_{\text {hitung }}=(J K R / k-1)\right) /(J K D /(n-k))$

$\mathrm{JKR}=$ jumlah kuadrat regresi

JKD = jumlah kuadrat residual

$\mathrm{n} \quad$ = jumlah sampel

$\mathrm{K}=$ jumlah variabel jika $F_{\text {hitung }} \leq F_{\text {tabel }}$, maka Ho diterima, artinya $\mathrm{xi}$ tidak berpengaruh nyata terhadap y

jika $F_{\text {hitung }}>F_{\text {tabel, }}$, maka Ho ditolak, artinya xi berpengaruh nyata terhadap $\mathrm{y}$

3. Uji F statistik Tintner, untuk memenuhi fungsi Cobb douglas memenuhi asumsi constan return to scale,

Ho : $\Sigma b i=1$

$\mathrm{H} 1: \Sigma \mathrm{bi} \neq 1$

$\mathrm{F}$ hitung $=\left(\left(\Sigma \mathrm{e}_{2}{ }^{2}-\Sigma \mathrm{e}_{1}{ }^{2}\right)(\mathrm{n}-\mathrm{k})\right) / \Sigma \mathrm{e}_{1}{ }^{2}$

Dimana :

$\Sigma \mathrm{e}_{1}^{2}=$ jumlah kuadrat sisa fungsi terbuka

$\Sigma \mathrm{e}_{2}{ }^{2}=$ jumlah kuadratsisa fungsi terbatas

$\mathrm{k}=$ jumlah variabel

$\mathrm{n}=$ jumlah sapel

$\mathrm{db}=1$

jika $F_{\text {hitung }} \leq F_{\text {tabel }}$, maka Ho diterima, artinya fungsi cobb douglas berada dalam kondisi constan return to scale jika $F_{\text {hitung }}>F_{\text {tabel }}$, maka Ho ditolak , artinya fungsi cobb douglas tidak berada dalam kondisi constan to scale

\section{HASIL DAN PEMBAHASAN}

\section{Gambaran Umum Perusahaan NONY}

Perusahaan NONY merupakan usaha keluarga yg didirikan oleh sepasang suami istri Suwarno dan Eni yang bertempat di desa Sambitan kecamatan Pekel kabupaten Tulungagung. Awal mula usaha sari kedelai ini didapatkan setelah mendapatkan pelatihan dan sosialisasi dari dinas perindustrian setempat. Pada mulanya hanya memproduksi 100 biji perhari, meningkat dari tahun 2010 ke tahun 2015 sampai sekarang menjadi rata - rata 5000 biji dengan kemasan 200ml per biji. Kini usahanya mampu menghasilkan omzet sebesar Rp.3.000.000-4.000.000 per hari dengan keuntungan bersih Rp.800.00 - 1.500.000. area pemasaran perusahaan ini adalah Tulungagung bagian selatan seperti wilayah kecamatan pakel, campurdarat, bandung, besuki, pucanglaban, tanggunggunung, kalidawir dan sebagian Kabupaten Trenggalek. 
Perusahaan NONY merupakan usaha keluarga yang memiliki banyak jenis usaha, namun yang menjadi usaha utama adalah pengolahan sari kedelai. Sari kedelai dikemas dalam berbagai kemasan seperti kemasan plastik $200 \mathrm{ml}$, gelas $240 \mathrm{ml}$, dan botol $300 \mathrm{ml}$. Selain itu NONY juga bergabung dengan berbagai unit usaha lain seperti kecap, air minum dan kerupuk, dengan memakai merek dagang NONY

perusahaan ini memiliki visi yang sangat menarik yaitu "terus memanfaatkan peluang sekecil apapun."

Sedangkan misi merupakan pernyataan dari apa yang harus dikerjakan untuk memperoleh cita-cita tersebut. Perusahaan NONY memiliki misi:

1. Meningkatkan kesejahteraan masyarakat dengan terus berwirausaha.

2. Memberdayakan dan membangun pebisnis yang tangguh di bidang usaha kecil menengah.

\section{Proses Produksi Sari Kedelai}

Berikut merupakan langkah - langkah pembuatan sari kedelai di perusahaan NONY.

1. Penyortiran, dengan tujuan untuk memilih biji-biji kedelai yang berkualitas baik. Penyortiran dilakukan dengan cara merendam biji kedelai yang akan di gunakan. Saring apabila ada kotoran yang mengapung. Pisahkan dari benda asing seperti plastik, batu dan kayu.

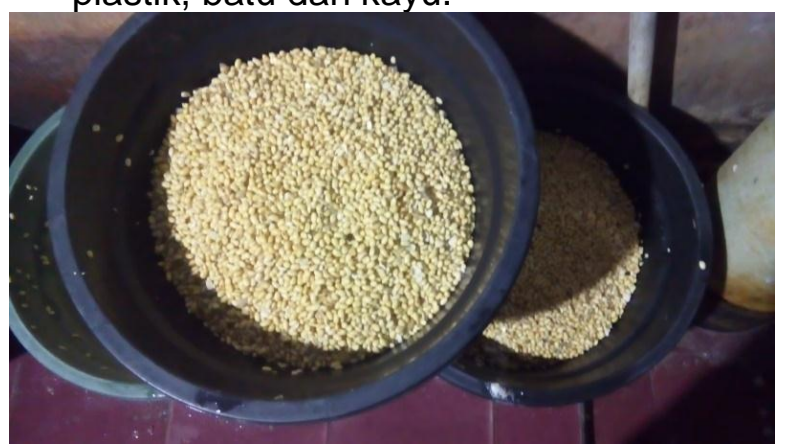

Kedelai Bersih Setelah Disortir

2. Pencucian, dengan tujuan menghilangkan kotoran-kotoran yang melekat pada biji kedelai. Pencucian ini dilakukan dengan air yang mengalir, kedelai di cuci manual agar debu kotoran yang menempel pada biji kedelai hilang.

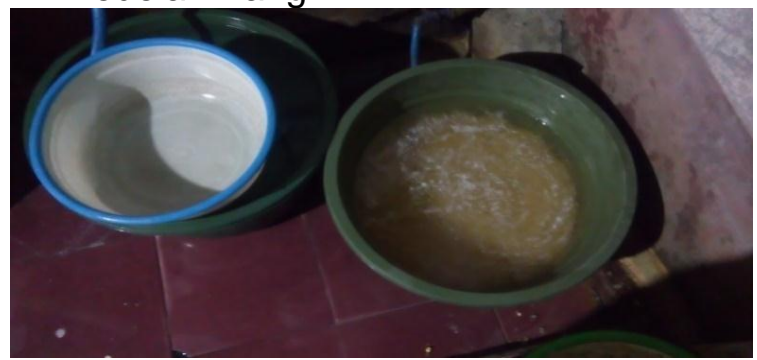

Kedelai Setelah di Cuci Direndam selama 10 -12 Jam

3. Perendaman, dengan tujuan untuk mempermudah dan mempercepat proses pelepasan kulit ari agar memudahkan proses penggilingan. Perendaman dilakukan selama 1012 jam agar kedelai mudah di proses.

4. Penggilingan dan Penyaringan .Penggilingan dilakukan dengan air dengan perbandingan $1: 4(\mathrm{~b} / \mathrm{v})$, dengan menggunakan perbandingan ini akan dihasilkan kekentalan seperti pada sari kedelai sapi dan juga akan didapatkan protein sari kedelai yang tinggi. Penyaringan, dengan tujuan untuk memperoleh sari kedelai. Filtrat inilah yang nantinya akan menjadi sari kedelai kedelai. Sementara ampasnya (limbah) dapat dimanfaatkan sebagai pakan ternak.

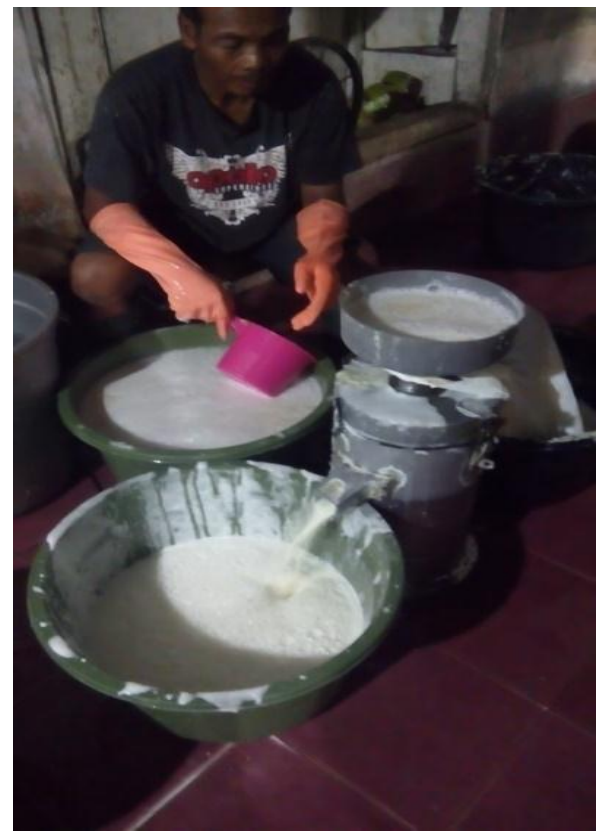




\section{Proses Penggilingan sekaligus Penyaringan}

5. Pemanasan, dilakukan pada proses akhir pembuatan sari kedelai dengan tujuan untuk mematikan semua organisme yang bersifat patogen dan sebagian mikroorganisme yang ada sehingga tidak merubah cita rasa maupun komposisi sari kedelai. Pada proses inilah terdapat proses pemberian perasa pada sari kedelai berupa gula, pewarna dan garam.

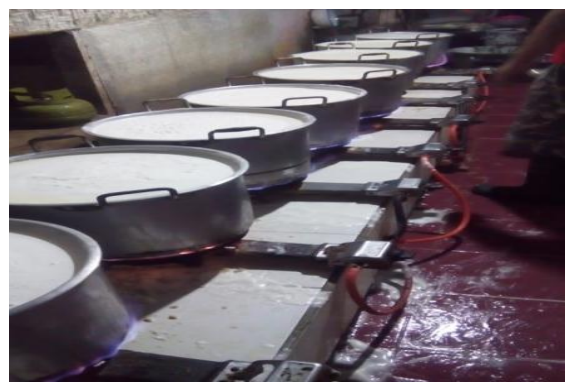

\section{Pemasakan Sari Kedelai}

6. Pengemasan.

Pengemasan

dilakukan dengan tujuan untuk melindungi sari kedelai dari kontaminasi, selain itu pengemasan dilakukan untuk memudahkan konsumen dalam mengenali dan mengkonsumsi produk. Pada hari biasa di kemasan yang digunakan berupa plastik 200ml, adapan kemasan Gelas $240 \mathrm{ml}$, botol $300 \mathrm{ml}$, dan $1 \mathrm{~L}$ dilakukan bila hanya ada pesanan saja.

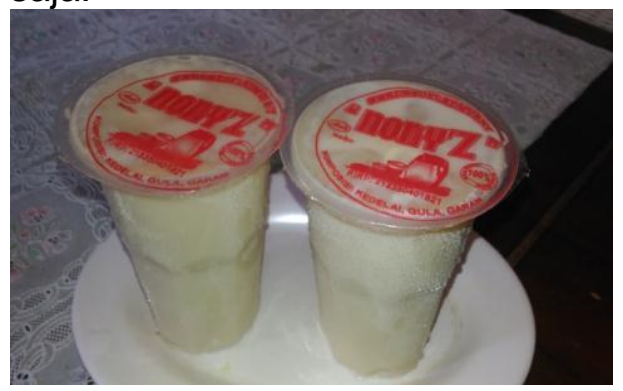

Produk Sari Kedelai NONY kemasan gelas

\section{Data Karakteristik Responden Penelitian}
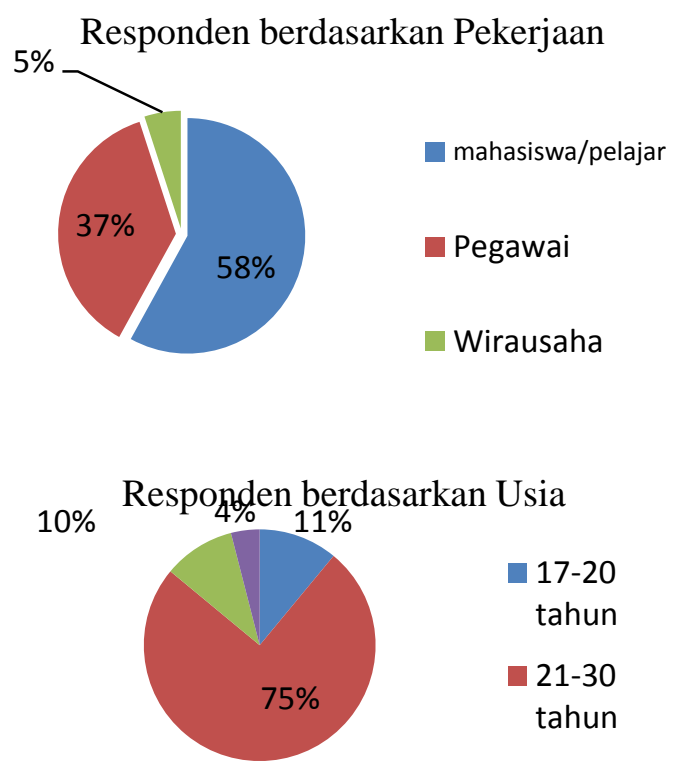

Responden berdasarkan Domisili

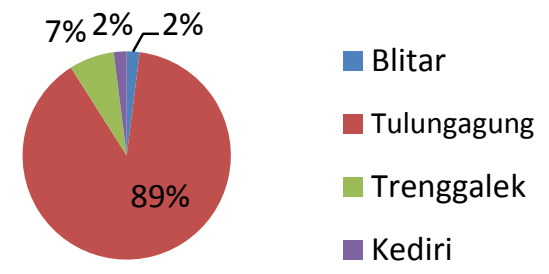

Berdasarkan diagram diatas menunjukkan bahwa konsumen sari kedelai NONY persentase terbanyak berusia 21-30 tahun dengan nilai $75 \%$, sementara untuk pekerjaan yang terbesar adalah mahasiswa atau pelajar dengan persentase $58 \%$, untuk domisili yang terbanyak berasal dari Tulungagung dengan $89 \%$.

\section{Analisis Pendugaan Fungsi Produksi Cobb Douglas \\ Berdasarkan faktor-faktor} produksi yang telah teridentifikasi, maka faktor produksi yang diduga berpengaruh terhadap produksi sari kedelai NONY 
meliputi kedelai (X1), air (X2), Gula (X3), Garam (X4), Perasa (X5), Tenaga kerja (X6) dan Investasi (X7). Faktor-faktor produksi tersebut akan dibuat dalam bentuk model fungsi produksi sari kedelai.
Dikarenakan fungsi cobb douglas merupakan fungsi non linier maka perlu dilakukan perubahan ke fungsi logaritmik. Setelah itu diuji secara linier kemudian dilakukan pengujian.

\begin{tabular}{|c|c|c|c|c|c|c|}
\hline \multicolumn{7}{|c|}{ Coefficients $^{a}$} \\
\hline \multirow{2}{*}{\multicolumn{2}{|c|}{ Model }} & \multicolumn{2}{|c|}{$\begin{array}{l}\text { Unstandardized } \\
\text { Coefficients }\end{array}$} & \multirow{2}{*}{$\begin{array}{c}\begin{array}{c}\text { Standardized } \\
\text { Coefficients }\end{array} \\
\text { Beta }\end{array}$} & \multirow[b]{2}{*}{$\mathrm{T}$} & \multirow[b]{2}{*}{ Sig. } \\
\hline & & $B$ & Std. Error & & & \\
\hline 1 & (Constant) & 2.141 & .299 & & 7.166 & .000 \\
\hline & Kedelai & .009 & .045 & .010 & .198 & .845 \\
\hline & Air & .022 & .052 & .011 & .424 & .676 \\
\hline & Gula & .923 & .079 & .926 & 11.634 & .000 \\
\hline & Garam & .069 & .074 & .074 & .930 & .363 \\
\hline & Perasa & -.031 & .066 & -.033 & -.464 & .647 \\
\hline & Pekerja & -.003 & .014 & -.002 & -.235 & .816 \\
\hline & Investasi & .013 & .016 & .015 & .812 & .426 \\
\hline & $\begin{array}{l}\mathrm{R}^{2} \\
\mathrm{R} \\
\text { Durbin Wat } \\
\text { alpha (a) } 5^{\circ}\end{array}$ & $\begin{array}{l}=0,999 \\
=1,000 \\
=2,134\end{array}$ & & $\begin{array}{l}\text { F-hitung }=623 \\
\text { Sig.F }=0,0\end{array}$ & & \\
\hline
\end{tabular}

$F$ hitung $623,309>2,46$ dengan nilai sig. $0,000<0,05$. Hasil uji $F$ tersebut bermakna faktor-faktor produksi yang dipredisikan di atas secara bersama-sama berpengaruh nyata dan signifikan terhadap tingkat produksi pada tingkat kepercayaan $95 \%$.

Berdasarkan tabel di atas dapat ditulis notasi persamaan linier fungsifungsi produksi sebagai berikut:

$$
\begin{aligned}
& \operatorname{Ln} Y=\operatorname{Ln} a+b 1 \operatorname{LnX} 1+b 2 \operatorname{LnX} 2 \\
& \text { +b3 LnX3 +b4 LnX4+b5 } \\
& \text { LnX4 +b5 LnX5 + b6 LnX6 } \\
& + \text { b7 LnX7 } \\
& Y=2.141+ \\
& 0,009 \times 1+0,022 \times 2+0,923 \times 3+0 \text {, } \\
& 069 \times 4+(-0,031 \times 5)+ \\
& (0,299) \quad(0,045) \quad(0,052) \\
& (0,079) \quad(0,074) \quad(0,066) \\
& \mathrm{t}=(7,166) \quad(0,198) \quad(0,424) \\
& (11,634) \quad(0,930) \quad(-0,464) \\
& (-0,003 \times 6)+0,013 \times 7 \\
& (0,014) \quad(0,016) \\
& (-235) \quad(0,812)
\end{aligned}
$$

Persamaan koefisien regresi variasi faktor-faktor produksi yang menjelaskan nilai uji t hitung dari seluruh faktor-faktor produksi penduga yang telah dianalisis menunjukkan hanya faktor gula (sig. $0,000<0,05)$ saja yang memiliki pengaruh nyata terhadap tingkat produksi susu kedelai. Sedangkan keenam faktor yang lain kedelai (sig.0,845), air (sig.0,676), garam (sig.0,363), perasa (sig.0,647), pekerja (sig.0,816), investasi (sig.0,426) terbukti tidak memiliki pengaruh nyata terhadap produksi susu kedelai,

Koefisien regresi pada perasa dan pekerja yang menghasilkan nilai negatif dapat dijelaskan karena penggunaan perasa yang berlebihan pada susu kedelai tidak disukai oleh konsumen sehingga akan berpengaruh terhadap omset penjualan susu kedelai, penjualan yang menurun akan mengakibatkan produksi susu kedelai diturunkan. Pada koefisien regresi pekerja dapat diduga penambahan jumlah pekerja akan meningkatkan beban biaya pada usaha susu kedelai, beban biaya produksi yang naik akan menyulitkan perusahaan untuk meningkatkan kapasitas produksi karena biaya operasional yang tidak efisien 


\section{Penggunaan Faktor Produksi Optimal Pada Kondisi Aktual dan Kondisi Optimal sari kedelai}

\begin{tabular}{llllllll}
\hline kondisi & $\begin{array}{l}\text { kedelai } \\
(\mathrm{kg})\end{array}$ & $\begin{array}{l}\text { air } \\
(\text { liter) }\end{array}$ & $\begin{array}{l}\text { gula } \\
(\mathrm{kg})\end{array}$ & $\begin{array}{l}\text { garam } \\
(\mathrm{kg})\end{array}$ & $\begin{array}{l}\text { perasa } \\
\text { (liter) }\end{array}$ & $\begin{array}{l}\text { pekerja } \\
\text { (orang) }\end{array}$ & $\begin{array}{l}\text { produksi } \\
\text { (liter) }\end{array}$ \\
\hline Actual & 156,26 & 1240 & 161,58 & 5,25 & 1 & 12,96 & 1000 \\
Optimal & 67,16 & 1538,5 & 54,29 & 3,45 & 0,51 & 6 & 1000 \\
\hline
\end{tabular}

Berdasarkan perbandingan data di atas dapat diketahui secara ekonomis produksi susu kedelai Nony belum efisien. Selanjutnya pada sisi teknis produksi susu kedelai Nony pada faktor produksi kedelai, perasa dan pekerja perlu dilakukan pengurangan jumlahnya pada kondisi aktual, sedangkan pada faktor produksi air dan garam perlu dilakukan penambahan, pada faktor produksi gula sebenarnya sudah efisien namun secara ekonomis perlu dilakukan pengurangan. Tentu saja pada saat dilakukan proses produksi secara teknis perlu dilakukan penambahan dan pengurangan pada beberapa faktor produksi, hal tersebut sesuai dengan kapasitas serta jumlah produksi yang sedang dilakukan oleh perusahaan susu kedelai Nony.

Analisis Bauran Pemasaran terhadap Kepuasan dan Loyalitas Konsumen Distribusi Kategorisasi Variabel Kepuasan Konsumen

\begin{tabular}{|c|c|c|c|c|}
\hline No & Skor & Katagori & Frekuensi & Presentase \\
\hline 1 & $\geq 4,52$ & Sangat Puas & 11 & 11 \\
\hline 2 & $4,52 \leq$ skor $\leq 3,54$ & Puas & 17 & 17 \\
\hline 3 & $3,54 \leq$ skor $\leq 2,56$ & Sedang & 38 & 38 \\
\hline 4 & $2,56 \leq$ skor $\leq 1,58$ & Tidak Puas & 34 & 34 \\
\hline 5 & $\leq 1,58$ & Sangat Tidak Puas & - & - \\
\hline \multicolumn{3}{|c|}{ Jumlah } & 100 & 100 \\
\hline
\end{tabular}

Berdasarkan tabel di atas indeks indikator variabel kepuasan konsumen dari responden penelitian dapat dijabarkan sebagai berikut, sebanyak $38 \%$ responden menyatakan sedang, sebanyak $34 \%$ menyatakan tidak puas, responden yang merasa sangat puas sebanyak $11 \%$, sedangkan yang merasa puas sebanyak $17 \%$.

Distribusi Kategorisasi Variabel Loyalitas Konsumen

\begin{tabular}{|c|c|c|c|c|}
\hline No & Skor & Katagori & Frekuensi & Presentase \\
\hline 1 & $\geq 14,51$ & Sangat Loyal & 6 & 6 \\
\hline 2 & $14,51 \leq$ skor $\leq 12,14$ & Loyal & 20 & 20 \\
\hline 3 & $12,14 \leq$ skor $\leq 9,76$ & Sedang & 44 & 44 \\
\hline 4 & $9,76 \leq$ skor $\leq 7,39$ & Tidak Loyal & 29 & 29 \\
\hline 5 & $\leq 7,39$ & Sangat Tidak Loyal & 1 & 1 \\
\hline \multicolumn{3}{|c|}{ Jumlah } & 100 & 100 \\
\hline
\end{tabular}

Berdasarkan tabel di atas indeks indikator variabel loyalitas konsumen dari responden penelitian dapat dijabarkan sebagai berikut, sebanyak $44 \%$ responden menyatakan sedang, sebanyak $29 \%$ menyatakan tidak puas, responden yang merasa sangat puas sebanyak $6 \%$, sedangkan yang merasa puas sebanyak $20 \%$.
Berdasarkan besarnya koefisien korelasi dan signifikansi , maka di dalam analisis bauran pemasaran pelaksanaan strategi yang perlu diutamakan dalam meningkatkan kepuasan konsumen berdasarkan prioritasnya sesuai urutan adalah 1) product, 2) harga, 3) promotion, 4) proses, 5) physical evidence, 6) place, 7 ) people. Pada kasus perusahaan susu 
kedelai NONY kepuasan konsumennya hanya dapat diprediksikan dengan variabel product dengan banyakya varian produk susu kedelai maka konsumen memiliki banyak pilihan dalam meminum susu kedelai sehingga meningkatkan kepuasan konsumen dalam menikmati produk susu kedelai. Selanjutnya price memberikan kontribusi nyata terhadap kepuasan konsumen dengan asumsi harga yang tepat dan terjangkau terhadap sebuah produk berpengaruh nyata, dengan harga yang sesuai maka konsumen merasakan kepuasan dalam menikmati produk susu kedelai. Pada variabel promotion sebagai upaya untuk mengenalkan produk dan memperluas pasar susu kedelai NONY terbukanya pasar menunjukkan susu kedelai disukai oleh konsumen. Semakin banyak dikenal maka kepuasan konsumen akan meningkat.

Berdasarkan besarnya koefisien korelasi dan signifikansi tersebut, maka di dalam analisis bauran pemasaran pelaksanaan strategi yang perlu diutamakan dalam meningkatkan loyalitas konsumen berdasarkan prioritasnya sesuai urutan adalah 1) promotion, 2) place, 3) people, 4) physical evidence, 5) proses, 6) product, 7) harga.

Temuan yang menarik dalam penelitian ini, jika dalam membentuk kepuasan konsumen faktor harga memiliki kontribusi nyata sedangkan pada pembentukan loyalitas ternyata harga tidak berkontribusi nyata dan signifikan, tentu saja hal ini dapat dijelaskan bahwa pada jangka panjang bagi konsumen yang memiliki loyalitas tinggi berapapun harga yang ditetapkan bukan menjadi persoalan lagi asalkan kualitas produk yang dibeli sesuai dengan ekpektasi konsumen, bagi konsumen yang baru mencoba sebuah produk maka harga akan menjadi pertimbangan pertama saat memutuskan membeli sebuah produk. Harga yang sesuai akan mudah menumbuhkan kepuasan konsumen jika kualitas produk menurut konsumen sudah layak. Selain itu temuan lain tercatat variabel place, people, dan physical evidence ternyata berkontribusi yang signifikan dalam membentuk loyalitas konsumen padahal variabel tersebut tidak secara langsung berhubungan dengan produk susu itu sendiri, termasuk juga hanya varaibel promosi yang berkontribusi langsung baik terhadap kepuasan ataupun loyalitas konsumen, tentu saja dalam melakukan promosi yang tepat dan efisien akan berkontribusi nyata terhadap kepuasan dan loyalitas konsumen.

\section{Implikasi Manajerial dari Hasil Evaluasi Bauran Pemasaran dan Analisis Faktor Produksi yang Dilakukan Industri Sari kedelai NONY}

1. Product Variabel product terbukti tidak
berkontribusi dalam membentuk loyalitas konsumen susu kedelai NONY, hal tersebut mengingat loyalitas konsumen susu ternyata tidak terbukti dari variasi produk yang dikeluarkan perusahaan, konsumen loyal biasanya tidak terlalu memperdulikan varian produk tetapi terhadap kualitas produk itu sendiri semakin perusahaan mampu menjaga kualitas rasa susu kedelai akan semakin loyal konsumen. Perusahaan susu kedelai NONY perlu membangun strategi produk yang tepat dan sesuai, sehingga mampu meningkatkan kepuasan konsumen sekaligus menjaga loyalitas konsumen yang sudah lama menjadi pelanggan susu kedelai.

\section{Price}

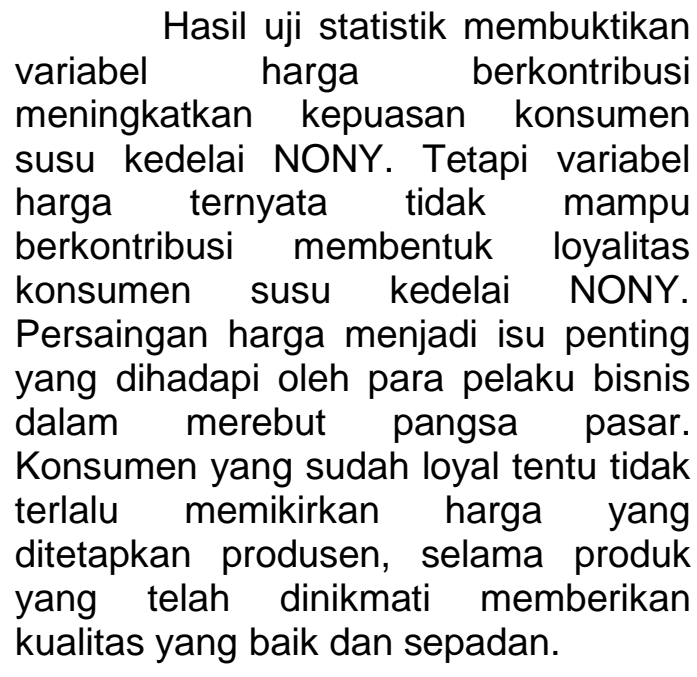

\section{People}

Perusahaan perlu membangun hubungan dengan konsumen loyal 
yang menjadi pelanggan tetap produk susu kedelai, sebab dengan memberikan kepercayaan pada konsumen maka akan mudah untuk memasarkan produk susu kedelai. Semakin dikenal pemilik perusahaan, dan pelayanan yang diberikan maka susu kedelai akan meningkatkan loyalitas konsumen.

\section{Proses}

Temuan penelitian tersebut dapat dijelaskan dengan asumsi bahwa proses produksi sebuah produk memang tidak terlihat, konsumen hanya melihat hasil akhir sebuah produk itu sendiri, sehingga konsumen mengabaikan proses produksi dan hanya melihat akhir produk jadi susu kedelai

\section{Place}

Bagi konsumen yang sudah lama menjadi pelanggan, keberadaan tempat susu kedelai NONY menjadi sarana membangun loyalitas terhadap produk yang dihasilkan, hal tersebut berbeda bagi konsumen yang baru mengenal susu kedelai, variabel place tidak menjadi pertimbangan untuk meningkatkan kepuasan konsumen, karena konsumen hanya bersandar pada hasil produk jadi susu kedelai itu sendiri.

\section{Physical evidence}

. Dalam jangka pendek konsumen hanya melihat tampilan produk jadi susu kedelai saja tanpa melihat dimana produk tersebut di produksi dan bagaimana tampilan perusahaan produsen produk tersebut. Kepuasan konsumen hanya tumbuh jika kualitas rasa, tampilan susu kedelai disukai dan sesuai dengan selera konsumen. Selain itu pemberian label resmi pengujian makanan sangat penting dalam hal ini, seperti ijin edar, sertifikasi halal, sertifikasi badan BPPOM, dan lain - lain.

\section{Promotion}

Hasil uji statistik membuktikan bahwa variabel promotion berkontribusi dalam meningkatkan kepuasan konsumen dan juga membangun loyalitas konsumen susu kedelai NONY. Semakin baik strategi promosi yang digunakan maka akan mempermudah produk susu kedelai untuk dikenal masyarakat dan memperluas pasar produk. sebaik apapun produk yang dihasilkan tanpa dilakukan promosi yang tepat maka akan sulit sebuah produk akan dikenal dan diketahui konsumen.

\section{KESIMPULAN DAN SARAN}

\section{Kesimpulan}

Berdasarkan penelitian yang telah dilaksanakan didapatkan kesimpulan antara lain :

1. faktor-faktor produksi yang dipredisikan secara bersamasama berpengaruh terhadap tingkat produksi

2. faktor produksi gula berpengaruh signifikan positif terhadap tingkat produksi susu kedelai

3. Koefisien regresi pada garam,perasa dan pekerja yang menghasilkan nilai negatif dapat dijelaskan karena penggunaan perasa yang berlebihan pada susu kedelai tidak disukai oleh konsumen sehingga akan berpengaruh terhadap omset penjualan susu. Pada koefisien regresi pekerja dapat diduga penambahan jumlah pekerja akan meningkatkan beban biaya pada usaha susu kedelai, beban biaya produksi yang naik akan menyulitkan perusahaan untuk meningkatkan kapasitas produksi karena biaya operasional yang tidak efisien.

4. Variabel product, price dan promotion berpengaruh terhadap kepuasan konsumen

5. Analisis bauran pemasaran pelaksanaan strategi yang perlu diutamakan dalam meningkatkan loyalitas konsumen berdasarkan prioritasnya sesuai urutan adalah 1) promotion, 2) place, 
3) people, 4) physical evidence, 5) proses, 6) product, 7) harga.

6. Secara keseluruhan Kepuasan dan Loyalitas Konsumen masuk dalam kategori sedang.

7. Implikasi manajerial yang direkomendasikan bagi perusahaan adalah meningkatkan kinerja di masing - masing indikator seperti menjaga kualitas produksi, menjaga stabilitas harga, meningkatkan hubungan perusahaan dengan konsumen, meningkatkan strategi pemasarannya melalui media cetak, elektronik dan on line.

\section{Saran}

Berdasarkan simpulan yang telah diambil, didapatkan pula saran saran yang dapat diberikan, antara lain :

1. Bagi perusahaan NONY saran didasarkan pada kesimpulan penelitian yaitu memperbaiki kapasitas pada masing masing faktor produksi terutama gula. Berdasarkan hasil implikasi manajerial indikator yang paling berpengaruh terhadap kepuasan dan loyalitas konsumen adalah pemasaran, sehingga perlu ditingkatkan strategi pemasarannya.

2. Bagi penelitian lanjutan, perlu dianalisa lagi dengan variabel lainnya seperti penggunaan teknologi, penggunaan bahan bakar, biaya distribusi dan lain lain agar ditemukan kondisi paling optimal dalam proses produksi

3. Bagi pemerintah perlu diberikan lagi pelatihan tentang Kesehatan dan Keselamatan Kerja, dan pelatihan HACCP (hazard analytical critical control points bagi pelaku usaha khususnya makanan.

\section{DAFTAR PUSTAKA}

Adiningsih KP. 2012. Analisis Kepuasan dan Loyalitas Konsumen
Restoran Nasi Bebek Ginyo di Jakarta [tesis]. Bogor (ID): Magister Manajemen Bisnis, Institut Pertanian Bogor.

Andri Kiki A. 2015. Strategi Pemasaran UKM HeejouBags. IPB. Bogor

Cahyadi, W. 2007. Kedelai Khasiat dan Teknologi. Bumi Aksara. Jakarta

David W. Cravens. 1996. Strategic Marketing. Richard. P. Irwin Inc

Iryadini, Lisnawati. 2010. Analisis Faktor Produksi Industri Kecil Kerupuk Kabupaten Kendal. (Skripsi). Jurusan IImu Ekonomi Studi Pembangunan Universitas Diponegoro

Kementrian Perindustrian Republik Indonesia. 2014.Rancangan Strategis 2014-2019.

Kosasih NN. 2013. Analisis Bauran Pemasaran terhadap Kepuasan dan Loyalitas Pelanggan Warung Nasi Ampera di Jakarta [tesis]. Bogor (ID): Magister Manajemen Bisnis, Institut Pertanian Bogor.

Kotler P. 2000. Manajemen Pemasaran Jilid 2. Jakarta (ID). Bumi Aksara.

Kotler dan Amstrong. (2007). Dasar-Dasar Pemasaran. Jilid I. Edisi Kesembilan. Jakarta. PT Indeks.

Kotler, Philip dan Keller, Kevin Lane. 2007. Manajemen pemasaran (Edisi 12 jilid 2). Benyamin Molan (penerjemah). Marketing Management. PT. Indeks: Jakarta

Rukmana. 2002. Kedelai dan Pengolahannya. Kanisius. Jakarta

Samuel H, Foedjiawati. 2005. Pengaruh Kepuasan Konsumen terhadap Kesetiaan Merek (Studi Kasus: Restoran The Prime Steak\&Ribs Surabaya). Jurnal Manajemen dan Kewirausahaan vol 7 nomor 1 : 74-82.

Santoso,Budi. 1994. Susu dan Yoghurt Kedelai. Yogyakarta. Kanisius. 